\title{
Beyond the Classroom Walls: Edmodo in Saudi Secondary School EFL Instruction, Attitudes and Challenges
}

\author{
Fatimah Al-Kathiri ${ }^{1}$ \\ ${ }^{1}$ Curriculum and Instruction Department, King Saud University, Riyadh, Saudi Arabia \\ Correspondence: Fatimah Al-Kathiri, Curriculum and Instruction Department, King Saud University, Riyadh, \\ Saudi Arabia. E-mail: fatimakathiri@gmail.com
}

Received: September 16, 2014 Accepted: October 20, 2014 Online Published: December 17, 2014

doi:10.5539/elt.v8n1p189 URL: http://dx.doi.org/10.5539/elt.v8n1p189

\begin{abstract}
This paper investigates the prospects of integrating Edmodo into Saudi EFL female secondary school instruction. It concentrates on students' perceptions and challenges regarding Edmodo use and its effect on their attitudes towards EFL learning. The 42 participants were divided into two groups. The experimental group received traditional teaching plus a six-week daily interaction via Edmodo. The control group received traditional teaching only. Findings of the post-treatment questionnaire show that students' perceptions towards Edmodo were highly positive andthat although there were considerable challenges to its integration, it appeared to have excellent potential for generating more positive attitudes towards EFL learning.
\end{abstract}

Keywords: attitude, Edmodo, EFL students, web 2.0 technology

\section{Introduction}

\subsection{Background}

In the past, learning simply meant face-to-face lectures, reading books or printed handouts. It was considered impossible without classrooms, books and chalkboards. Today, technology has played a major role in the field of education especially with the emergence of the World-Wide Web. The Internet has become an increasingly important feature of the learning environment for students. According to the Internet World Stats, http://www.internetworldstats.com/stats.htm, the estimated number of Internet users around the world was approximately more than 2000 million by June 2012. The appearance of Web 2.0 technologies has also helped to promote and maintain the education standards. These tools allow multiple users to participate collaboratively rather than working alone. They offer many functions that appeal to educators who are looking to extend learning beyond the classroom (Haygood, Garner, \& Johnson, 2012). One of the most useful of these functions is Edmodo. It is a private micro-blogging service available at www.edmodo.com which provides a free and secure learning platform. It looks similar to Facebook, but is much more private and safe for a learning environment because it allows only teachers to create and manage accounts, and only their students, who receive a group code and register in the group, can access and join the group (Majid, 2011). This service is accessible through any mobile device with Internet capabilities including free appsproviding a simple way for teachers and students in a virtual class to connect and collaborate. Via Edmodo, teachers can send out quizzes and assignments, give feedback, receive completed assignments, assign grades, store and share content in the form of both files and links, maintain a class calendar, conduct polls, as well as send notes and text (SMS) alerts to individual students or to the entire class. It also offers parent accounts in which they can view their children's homework assignments and due dates and receive updates on class and school events. At the time of writing this paper, it is estimated that more than twenty-nine million teachers and students around the world are using Edmodo on daily basis (http://www.edmodo.com/about). Edmodo was also recognized by the American Association of School Librarians in 2011 as one of the top 25 websites that foster the qualities of innovation, creativity, active participation, and collaboration in the category entitled 'Social Networking and Communication' (Kongchan, 2012).

\subsection{Statement of the Problem}

In the Saudi context, unfortunately, Edmodo has not yet been used for enhancing the classroom experience because of the slow digital adoption in schools. Therefore, this study attempts to identify where Saudi students 
and teachers stand with respect to the value and implementation of this service. It examines in depth the usefulness and the challenges of integrating Edmodo as an educational tool in EFL classrooms and its effect on students' attitudes towards EFL learning. It also presents an effort to extend learning opportunities for students beyond the traditional classroom walls and to foster an environment that encourages students to take greater responsibility for their own learning.

\subsection{Research Questions}

The current study seeks answers to the following questions:

1) Are there any significant differences between the control and experimental groups in the post EFL learning attitude scale in relation to the use of Edmodo?

2) What are the Saudi secondary school female students' perceptions towards using Edmodo in their EFL learning?

3) What are the challenges faced by Saudi secondary school female students when using Edmodo in their EFL learning?

\section{Review of Literature}

\subsection{Saudi Students' Attitudes towards EFL Learning}

Gagne (1984) defines attitude as an "inferred internal state which influences behavior" (p. 383). Thus, attitude plays an important role in learning, including language learning, as it determines to a great extent the learners' behaviours (Alkaff, 2013). Al-Seghayer (2012) believes that, in general, Saudis' attitudes towards English are highly positive and that this attitude can be seen in the results of a number of empirical studies conducted in the past two decades on the attitude of Saudi people towards English language in general and learning it in particular. Alfawzan (2012), for example, examined the attitudes of 40 Saudi students enrolled in an intensive English program at a US university. His participants expressed strong support for the teaching of English as early as first grade in the Saudi school system. He also found out that "instrumental motivation" is the main "driving force" for those students. In Al-Zubeiry'sstudy (2012), the 120 secondary school male and female student participants showed positive attitudes towards learning English and were highly motivated in both instrumental and integrative orientations though the fact that there is a wide gap between the students' motivation and attitudes and the reflections in their performance. However, Alseweed (2009) believes that students' attitudes towards EFL learning cannot be viewed as stable. He concludes thatstudents' attitudes towards EFL learning may change according to the changing nature between learning settings of educational levels, the traditional methods of teaching, the students' achievement level and to the courses offered. Therefore, Al-Shammari (2007) recommendsto try out new innovative scenarios, such as Internet technologies, for the pursuit of excellence in Saudi EFL teaching and learning practices. However, he argues that the issue should not be that the learners use these technologies, but rather that the learners like and benefit from them.

\subsection{Web 2.0 Technologies in EFL Learning}

One of the most popular Web.2 technologies is social networking. It is basically a service provider that allows users to create system profiles and an online group network of users so that all the users in the group can interact with one another, share information and build an ongoing virtual community (Wolf \& College, 2007). Chen and Bryer (2012) believe that the notion of using social networking for educational purposes can be traced back to the theory of Social Constructivism in the 1960s. The basic principle of this theory, as proposed by Vygotsky (1978), is that students learn most effectively by engaging in carefully selected collaborative problem-solving activities, under the close supervision of instructors. Years later, Siemens (2004) and Downes (2007) launched the Connectivism Theory, where social learning is integrated with social media technologies. According to Siemens (2004) the true competence for a lifelong learner would be the capability to "stay connected" and "belong" to digital communities with which interests are and can be continuously shared. Turkmen (2012) attempted to investigate the usefulness of social networking sitesas a meaningful learning environment that could support, enhance and/or strengthen EFL learning. His findings indicate that if applied properly with certain aims, a social networking site that reminds students of their daily life can provide learners with a frame to assist them in structuring and coordinating acts of knowledge construction. He concludes that combining the Internet social networking options with the curriculum helps the students learning a second language in various ways, including increasing participation and motivation. In Saudi Arabia, many researchers have also called for EFL teachers to utilize this technology in order to support teaching and learning activities. Al-Shehri (2011), for example, tries to explore the potential of using mobile phones and social networking as tools of contextualizing language learning. He concludes that mobile social networking media can provide rich learner-generated and appropriate 
out-of-class language learning opportunities that exploit the norms of the learning context. Al-Shahrani (2012) adds that there is an urgent need for Saudi EFL teachers to consider such technologies in their teaching to reach students through the channels they are already accustomed to.

Another Web.2 tool is the technology of course management systems (CMS). Meerts (2003, p. 5) defines itas a service that "provides the instructor with a set of tools and a framework that allow the relatively easy creation of online course content and the subsequently management of that course including various interactions with students taking the course". According to Techopedia, such systems may includeadministrative as well as teaching aspects. They may also include tools for real-time chat, or asynchronous bulletin board type communications. Wu\& Hua (2008) believe that the integration of such a technology has been a trendy feature in the past ten years for higher education institutes all around the world. Tsai and Ernst (2009) reporton the implementation of Moodleas a CMS tool to assist EFL reading instruction for Chinese-speaking EFL learners. Their results reveal that CMS can facilitate and improve students' reading comprehension performance. Robertson (2008) also believes that the implementation of such a technology can have a beneficial impact on EFL course organization, lesson implementation, coursework distribution, teacher-student communication and assessment and it can also create a more student-centered learning experience. This view is further supported by many Saudi studies. Al-Jarf (2005), for example, examined the use of three CMS tools, Nicenet, WebCT and Moodle, to teach grammar to freshman EFL students at the College of Languages and Translation at King Saud University in Riyadh. Her results showed that Nicenet was the most popular and powerful tool for improving students' achievement in grammar. Aljabre (2012) also thinks that implementing The Blackboard system in some Saudi universities have many benefits allowing students to access content materials, participate in real-time quizzes and to exchange files with their instructors.

Many Web.2 tools offerMobile apps for their users. Attewell et al (2009) defined mobile learning as "the exploitation of ubiquitous handheld technologies, together with wireless and mobile phone networks, to facilitate, support, enhance and extend the reach of teaching and learning" (p. 11). Today, many useful mobile apps have been produced and increasingly used for language learning . In Coffey's research (2012), he found that $31 \%$ of his 290 respondents reported using a mobile device to help with language learning, 35\%agreed that an advantage of apps was that they allowed learning outside a school or other formal environments and $34 \%$ saw a benefit in apps as being an additional meansof language practice. In the field of EFL learning, Motiwalla (2007) believes that the use of a well-balanced combination of classroom pedagogies with mobile learning services would support both interactive and collaborative EFL learning and effectively deliver the content. In Saudi Arabia, the results of Hanafiah's (2012)study proves that though students' usage of mobile language apps is limited to translation activity, search for vocabulary and chatting, yet these apps are found to be relevant and only a limited number of students face problems using them.

\subsection{Using Edmodo in EFL Learning}

Arroyo (2011) sees Edmodo as an excellent communication tool for knowledge construction based on social networking andcollaboration providing a more secure learning platform for learners and educators. Witherspoon (2011) sees it as a great CMS tool for helping teachers to set up and manage their online classes easilyallowing students to control their own learning pace. For Fujimoto (2012), the free Edmodo Mobile apps allow learners to access any recorded resources wherever they are and whenever they like. Thongmak (2013), using Thailand case, attempted to study the acceptance of Edmodo as a classroom collaboration tool and to explore university students' views about it. His results, collected from 182 questionnaires, reveal that Edmodo can be more beneficial than any other social networks for various areas of education. It can also be used to support both distance teaching and to fulfill physical classroom learning. In his survey to 200 Edmodo users who take English subjects at Telkom Polytechnic, Majid (2011) stated that 66\% of students agree that Edmodo is useful, $79 \%$ agree that it helps them to face their study and 78\% feel happy for having this site integrated with their English classes. From another prospective, the results of Kongchan'sstudy (2012) revealed that Edmodo was perceived to be a wonderful and user-friendly social learning network that enables a 57-year-old teacher of English at King Mongkut's University of Technology Thonburi in Thailand to take charge of her own exploring and making use of the site to set up and run her online classes. Such results prove that Edmodo, having a high level of acceptance, can be used not only as a tool to create an additional online classroom community for students but can benefit the teacher community as well.

\subsection{Challenges of Using Edmodo}

Grosseck (2009) argues that the alliance between Web.2 technologies and the teaching-learning process poses a series of challenges such as the requirement of Internet connection and the need for high digital abilities. Zaidieh 
(2012) explores deeper challenges such as the bad effect on students' health and the lack of physical clues like tone, inflection and body language that are offered in face-to-face interaction. In the Saudi context, Al-Asmari (2005) believes that the factors most influencing the low level of use of the Internet technologies were EFL teachers' perceived expertise, place of access and Internet training. Similarly, Barnawi's study (2009) indicates that the lack of technology resources and the imposition of traditional methods of instructional delivery could be possible internal and external impediments to the use of Internet technologies in the classroom. Alebaikan and Troudi (2010) add that because Saudi students have not experienced online learning, a number of students may struggle with acquiring the crucial skills to function well in such a learning environment. According toAlmaini'sresults (2013) teacher resistance, lack of training, and budgetary or resource constraints are the main issues that contribute to the failure to exploit fully the potential of these technologies. Stroud (2010) also enumerates some of the problems that may occur when using Edmodo, such as the low-income students, the long time spent in front of the computer and the possibility of using it as more of a social networking site than as an educational tool. Furthermore, the mobile apps of Edmodo service may cause another challenge. Stockwell (2008) and Motiwalla (2007) argue thatsmall-sized screens, time-consuming typing and slow speeds of connection can reveal an evidence of resistance.

\section{Methodology}

\subsection{Design}

The design of the research isa field quasi-experimental design which is often used in educational research where it is simply not possible for the examiner to randomly allocate participants to control or experimental groups (Cohen, Manion, \& Morrison, 2007). The experimental group received the traditional teaching plus a daily interaction between students and their teacher through Edmodoas an additional online classroom community. The control group received the traditional teaching only. The students' attitudes towards EFL learning in the post-measure were compared for both groups in order to determine whether there were significant differences in relation to the treatment. The experimental group studentswere also requested to respond to a post questionnaire to find out how they felt about their experience with Edmodo and what challenges they faced.

\subsection{Participants}

The participants were 42 female second grade students at The $4^{\text {th }}$ Secondary School in Riyadh, a public school supervised by the Saudi Ministry of Education. All participants were in the scientific section, their ages ranged from 17 to 19 years and they had studied English for no less than 5 years at schools. 21 students constituted the experimental group and 21 students constituted the control group. Both groups were studying English with the same Saudi female teacher who had a fifteen-year experience in EFL teaching. A pre-performance attitude comparison has been done between the two groups in order to ensure that students were at the same attitude level towards EFL learning.

Table 1. Pre-performance EFL learning attitude scale for both groups

\begin{tabular}{lllllll}
\hline Group & $\mathrm{N}$ & Mean Rank & Sum of Ranks & Mann-Whitney U & Z & Sig.(2 tailed) \\
\hline Experimental & 21 & 20.71 & 435.00 & 204.000 & \multirow{2}{*}{-.419} & .675 \\
Control & 21 & 22.29 & 468.00 & & & \\
\cline { 1 - 4 } Total & 42 & & & & \\
\hline
\end{tabular}

Table 1 indicates that both groups scored similarly $(.675 \mathrm{p}<.05)$.

\subsection{Instruments}

One questionnaire with a three-point scale (Agree-Neutral-Disagree) was utilized in the present study. This questionnaire, designed by the researcher, was divided into three sections.

1) A pre-post attitude scale containing 13 items for measuring students' attitudes towards EFL learningbefore and after the treatment. These items cover four dimensions; liking, difficulty, integrative as well as instrumental values of EFL learning.

2) A post attitude scale containing 19 items for identifying the perceptions of experimental group students towards the use of Edmodo. These items cover four dimensions; social interaction, course management systems, language skills development and pedagogical purposes. 
3) A post attitude scale containing 6 items for identifying obstacles faced by experimental group students when using Edmodo. An open-ended response item was also added at the end for students' further comments (Appendix A).

\subsection{Pilot Study}

The Arabic version of the questionnaire (Appendix B) was piloted to 20 students, who had similar characteristics of gender, age, grade and EFL study experience to those of the main study.

Table 2. Validity correlations coefficients

\begin{tabular}{ll}
\hline Questionnaire Sections & Correlation with the total score of the questionnaire \\
\hline Attitudes towards EFL learning & $0.84^{* *}$ \\
Perceptions towards using Edmodo & $0.74^{* *}$ \\
Challenges of using Edmodo & $0.65^{* *}$ \\
\hline
\end{tabular}

As it can be seen in Table 2 the reliability analysis produced a Cronbach's Alfa of (0.74). The validity analysis also produced significant correlations.

\subsection{Data Collection \& Analysis}

In September 2013, the researcher started carrying out the main study pursuing the following procedures:

- Prior to conducting the study, students' attitudes towards EFL learning were pre-scaled for both groups.

- Two Edmodo workshops were held for the teacher and the experimental group students in order to create accounts, download mobile apps and explain the main features and services of the website.

- A daily interaction between the experimental group students and their teacher via Edmodo was allowed as to create an additional online classroom community when they were at home. Daily interaction was done through: posting assignments, feedback and class materials, conducting polls and quizzes, chatting in small groups and doing extracurricularactivities.

- Six weeks later, the experimental group students were requested to answer a questionnaire that aimed at finding out how they felt about their experience with Edmodo and what challenges they faced during this experience.

- In a separate session, students' attitudes towards EFL learning were post-scaled for both groups then compared in order to determine whether there were any significant differences between the two groups in relation to the treatment.

\section{Results}

\subsection{Testing the First Question}

A pre-performance attitude comparison has been done between the experimental and control groups in order to ensure that the subjects are at the same attitude level towards EFL learning. The results show that the EFL learning attitudes of both groups are generally positive.

Table 3. Pre-performance comparison between the two groups in EFL learning attitude scale

\begin{tabular}{|c|c|c|c|c|c|c|c|}
\hline Dimensions of Scale & Group & $\mathrm{N}$ & $\begin{array}{l}\text { Mean } \\
\text { Rank }\end{array}$ & $\begin{array}{l}\text { Sum of } \\
\text { Ranks }\end{array}$ & $\begin{array}{l}\text { Mann- } \\
\text { Whitney U }\end{array}$ & $\mathrm{Z}$ & $\begin{array}{l}\text { Sig. (2 } \\
\text { tailed) }\end{array}$ \\
\hline \multirow{3}{*}{ Liking } & Experimental & 21 & 19.29 & 405.00 & \multirow{2}{*}{174.000} & \multirow{2}{*}{-1.213} & \multirow{3}{*}{.225} \\
\hline & Control & 21 & 23.71 & 498.00 & & & \\
\hline & Total & 42 & & & & & \\
\hline \multirow{3}{*}{ Difficulty } & Experimental & 21 & 21.07 & 442.50 & \multirow{2}{*}{211.500} & \multirow{2}{*}{-.230} & \multirow{3}{*}{.818} \\
\hline & Control & 21 & 21.93 & 460.50 & & & \\
\hline & Total & 42 & & & & & \\
\hline
\end{tabular}




\begin{tabular}{|c|c|c|c|c|c|c|c|}
\hline \multirow{3}{*}{ Integrative values } & Experimental & 21 & 22.55 & 473.50 & \multirow{2}{*}{198.500} & \multirow{2}{*}{-.681} & \multirow{3}{*}{496} \\
\hline & Control & 21 & 20.45 & 429.50 & & & \\
\hline & Total & 42 & & & & & \\
\hline \multirow{3}{*}{ Instrumental values } & Experimental & 21 & 21.55 & 452.50 & 210500 & 026 & \multirow{3}{*}{979} \\
\hline & Control & 21 & 21.45 & 450.50 & 21.000 & .020 & \\
\hline & Total & 42 & & & & & \\
\hline \multirow{3}{*}{ Total } & Experimental & 21 & 20.71 & 435.00 & 204000 & 410 & \multirow{3}{*}{.675} \\
\hline & Control & 21 & 22.29 & 468.00 & & & \\
\hline & Total & 42 & & & & & \\
\hline
\end{tabular}

Table 3 shows that the Z-score is $(z=-.419, p=.67)$ which means that no significant differences between the two groups have been identified. A post performance attitude comparison has also been done between the two groups to detect any distinction in their EFL learning attitudes in relation to the treatment.

Table 4. Post performance comparison between the two groups in EFL learning attitude scale

\begin{tabular}{|c|c|c|c|c|c|c|c|}
\hline Dimensions of Scale & Group & $\mathrm{N}$ & $\begin{array}{l}\text { Mean } \\
\text { Rank }\end{array}$ & $\begin{array}{l}\text { Sum of } \\
\text { Ranks }\end{array}$ & $\begin{array}{l}\text { Mann- } \\
\text { Whitney U }\end{array}$ & Z & $\begin{array}{l}\text { Sig. (2 } \\
\text { tailed) }\end{array}$ \\
\hline \multirow{3}{*}{ Liking } & Experimental & 21 & 25.02 & 525.50 & 146500 & \multirow{3}{*}{-1.941} & \multirow{3}{*}{.050} \\
\hline & Control & 21 & 17.98 & 377.50 & 140.500 & & \\
\hline & Total & 42 & & & & & \\
\hline \multirow{3}{*}{ Difficulty } & Experimental & 21 & 27.95 & 587.00 & & \multirow{3}{*}{-3.515} & \multirow{3}{*}{.000} \\
\hline & Control & 21 & 15.05 & 316.00 & 0.000 & & \\
\hline & Total & 42 & & & & & \\
\hline \multirow{3}{*}{ Integrative values } & Experimental & 21 & 24.57 & 516.00 & 156000 & \multirow{3}{*}{-2.181} & \multirow{3}{*}{.029} \\
\hline & Control & 21 & 18.43 & 387.00 & 150.000 & & \\
\hline & Total & 42 & & & & & \\
\hline \multirow{3}{*}{ Instrumental values } & Experimental & 21 & 23.17 & 486.50 & $185 \quad 500$ & \multirow{3}{*}{-1.106} & \multirow{3}{*}{.269} \\
\hline & Control & 21 & 19.83 & 416.50 & 103.500 & & \\
\hline & Total & 42 & & & & & \\
\hline \multirow{3}{*}{ Total } & Experimental & 21 & 28.79 & 604.50 & 67500 & \multirow{3}{*}{-3.886} & \multirow{3}{*}{.000} \\
\hline & Control & 21 & 14.21 & 298.50 & 07.500 & & \\
\hline & Total & 42 & & & & & \\
\hline
\end{tabular}

The results show that there is a statistically significant difference between the mean rank score of the experimental group (28.79) and that of the control group (14.21) in favor of the experimental group. Table 4 shows that the only dimension that has no significant differences is theinstrumental values of EFL learning whereas thethree other dimensions have all shown significant differences in favor of the experimental group. A third comparison has also been made between the pre and post EFL learning attitude scales of the experimental group. 
Table 5. Comparison between pre and post EFL learning attitude scales of the experimental group

\begin{tabular}{|c|c|c|c|c|c|c|c|}
\hline Dimensions of Scale & Group & $\mathrm{N}$ & $\begin{array}{l}\text { Mean } \\
\text { Rank }\end{array}$ & $\begin{array}{l}\text { Sum of } \\
\text { Ranks }\end{array}$ & $\begin{array}{l}\text { Mann- } \\
\text { Whitney U }\end{array}$ & Z & $\begin{array}{l}\text { Sig. (2 } \\
\text { tailed) }\end{array}$ \\
\hline \multirow{3}{*}{ Liking } & Pre & 21 & 16.55 & 347.50 & 116500 & \multirow{3}{*}{-2.703} & \multirow{3}{*}{.007} \\
\hline & Post & 21 & 26.45 & 555.50 & 110.500 & & \\
\hline & Total & 42 & & & & & \\
\hline \multirow{3}{*}{ Difficulty } & Pre & 21 & 15.33 & 322.00 & 010100 & \multirow{3}{*}{-3.358} & \multirow{3}{*}{.001} \\
\hline & Post & 21 & 27.67 & 581.00 & 91.000 & & \\
\hline & Total & 42 & & & & & \\
\hline \multirow{3}{*}{ Integrative values } & Pre & 21 & 19.43 & 408.00 & 17700 & \multirow{3}{*}{-1.999} & \multirow{3}{*}{.050} \\
\hline & Post & 21 & 23.57 & 495.00 & 171.000 & & \\
\hline & Total & 42 & & & & & \\
\hline \multirow{3}{*}{ Instrumental values } & Pre & 21 & 20.62 & 433.00 & & \multirow{3}{*}{-.526} & \multirow{3}{*}{.599} \\
\hline & Post & 21 & 22.38 & 470.00 & 202.000 & & \\
\hline & Total & 42 & & & & & \\
\hline \multirow{3}{*}{ Total } & Pre & 21 & 13.76 & 289.00 & 58000 & \multirow{3}{*}{-4.127} & \multirow{3}{*}{.000} \\
\hline & Post & 21 & 29.24 & 614.00 & 58.000 & & \\
\hline & Total & 42 & & & & & \\
\hline
\end{tabular}

The results show that there is a statistically significant difference between the mean rank score of the pre-performance attitude scale (13.76) and that of the post performance attitude scale (29.24) in favor of the latter. Table 5 shows that theinstrumental values of EFL learning is the only dimension that has no significant differences whereas thethree otheroneshave significant differences in favor of the post scale.

\subsection{Testing the Second Question}

A descriptive statistical analysis of students' perceptions towards the integration of Edmodo in EFL learninghas been made. The results showthat students' perceptions are highly positive.

Table 6. Descriptive statistics of students' perceptions towards using Edmodo

\begin{tabular}{llllll}
\hline Dimensions of Scale & $\mathrm{N}$ & Mean & Std. Deviation & Percentage & Rank \\
\hline As a social interaction tool & 21 & 8.4762 & .81358 & 92 & 4 \\
As a learning management system & 21 & 11.0476 & .86465 & 94 & 3 \\
Development of language skills & 21 & 17.2381 & .88909 & 96 & 2 \\
Pedagogical purposes & 21 & 17.5714 & .81064 & 98 & 1 \\
Total & 21 & 54.3333 & 2.15252 & 95 & \\
\hline
\end{tabular}

Table 6 shows that the highest mean value (17.57) is for the pedagogical purposes of Edmodo. The second rank is for the development of language skills through Edmodo with a mean scoring (17.23). The third rank is for Edmodo as a learning management system with a mean scoring (11.04). The last rank is for Edmodo as a social networking tool with a mean scoring (8.47). 
Table 7. Rank, median and standard deviation values of students' perceptions towards using Edmodo

\begin{tabular}{|c|c|c|c|c|c|c|c|c|}
\hline \multirow{2}{*}{ No } & \multirow{2}{*}{ Item } & \multirow{2}{*}{$\begin{array}{l}\text { Frequency/ } \\
\text { Percentage }\end{array}$} & \multicolumn{3}{|l|}{ Options } & \multirow{2}{*}{ Median } & \multirow{2}{*}{$\begin{array}{l}\text { Standard } \\
\text { Deviation }\end{array}$} & \multirow{2}{*}{ Rank } \\
\hline & & & Dis-agree & Neutral & Agree & & & \\
\hline \multirow{2}{*}{1} & \multirow{2}{*}{$\begin{array}{l}\text { Edmodo meets my needs } \\
\text { such as mobility and social } \\
\text { communication. }\end{array}$} & $\mathrm{F}$ & 1 & 4 & & \multirow{2}{*}{2.714} & \multirow{2}{*}{0.560} & \multirow{2}{*}{7} \\
\hline & & $\mathrm{P}$ & 4.8 & 19.0 & 76.2 & & & \\
\hline \multirow{2}{*}{2} & \multirow{2}{*}{$\begin{array}{l}\text { Edmodo offers me more } \\
\text { opportunities to interact with } \\
\text { my teacher and peers outside } \\
\text { classroom. }\end{array}$} & $\mathrm{F}$ & .0 & 2.0 & 19.0 & \multirow{2}{*}{2.904} & \multirow{2}{*}{0.300} & \multirow{2}{*}{3} \\
\hline & & $\mathrm{P}$ & 0 & 9.5 & 90.5 & & & \\
\hline \multirow[b]{2}{*}{3} & \multirow{2}{*}{$\begin{array}{l}\text { Students who are shy to } \\
\text { participate in class, usually } \\
\text { feel more comfortable } \\
\text { communicating online via } \\
\text { Edmodo }\end{array}$} & $\mathrm{F}$ & 0 & 3 & 18 & \multirow[b]{2}{*}{2.857} & \multirow[b]{2}{*}{0.358} & \multirow[b]{2}{*}{4} \\
\hline & & $\mathrm{P}$ & 0 & 14.3 & 85.7 & & & \\
\hline \multirow{2}{*}{4} & \multirow{2}{*}{$\begin{array}{l}\text { Edmodo saves effort and } \\
\text { time by doing and submitting } \\
\text { assignments electronically. }\end{array}$} & $\mathrm{F}$ & 0 & 8 & 13 & \multirow{2}{*}{2.619} & \multirow{2}{*}{0.497} & \multirow{2}{*}{8} \\
\hline & & $\mathrm{P}$ & 0 & 38.1 & 61.9 & & & \\
\hline \multirow[b]{2}{*}{5} & \multirow{2}{*}{$\begin{array}{l}\text { Edmodoservices like (SMS } \\
\text { messages, alerts, notes) give } \\
\text { me a running record of } \\
\text { assignments' due date and a } \\
\text { description of what is } \\
\text { expected. }\end{array}$} & F & 0 & 0 & 21 & \multirow[b]{2}{*}{3} & \multirow[b]{2}{*}{0} & \\
\hline & & $\mathrm{P}$ & 0 & 0 & 100 & & & 1 \\
\hline 6 & $\begin{array}{l}\text { When absent, I can easily } \\
\text { access class materials and }\end{array}$ & $\mathrm{F}$ & 0 & 3 & 18 & 2857 & 0358 & 4 \\
\hline 0 & $\begin{array}{l}\text { assignments } \quad \text { through } \\
\text { Edmodo. }\end{array}$ & $\mathrm{P}$ & 0 & 14.3 & 85.7 & ו & 0.00 & T \\
\hline & Edmodoreduceslearning cost & $\mathrm{F}$ & 2 & 5 & 14 & & & \\
\hline 7 & $\begin{array}{l}\text { (e.g. photocopying, designing } \\
\text { posters). }\end{array}$ & $\mathrm{P}$ & 9.5 & 23.8 & 66.7 & 2.571 & 0.676 & 9 \\
\hline & Edmodo helps me practicing & $\mathrm{F}$ & 0 & 4 & 17 & & & \\
\hline 8 & $\begin{array}{l}\text { my language skills through } \\
\text { conversations. }\end{array}$ & $\mathrm{P}$ & 0 & 19 & 81 & 2.809 & 0.402 & 5 \\
\hline & Edmodogives me a chance to & $\mathrm{F}$ & 0 & 1 & 20 & & & \\
\hline 9 & $\begin{array}{l}\text { share my writing with my } \\
\text { teacher and peers. }\end{array}$ & $\mathrm{P}$ & 0 & 4.8 & 95.2 & 2.952 & 0.218 & 2 \\
\hline 10 & Edmodo helps me acquiring & $\mathrm{F}$ & 0 & 0 & 21 & 3 & 0 & 1 \\
\hline & new English vocabulary. & $\mathrm{P}$ & 0 & 0 & 100 & 3 & 0 & 1 \\
\hline & $\begin{array}{l}\text { Edmodohelps to improve my } \\
\text { spelling and grammar when }\end{array}$ & $\mathrm{F}$ & 0 & 3 & 18 & & & \\
\hline 11 & $\begin{array}{l}\text { posting in complete words } \\
\text { and sentences ("you" not } \\
\text { "u",'I" not "ii"). }\end{array}$ & $\mathrm{P}$ & 0 & 14.3 & 85.7 & 2.857 & 0.358 & 4 \\
\hline & Edmodohelps to make my & $\mathrm{F}$ & 0 & 3 & 18 & & & \\
\hline 12 & $\begin{array}{l}\text { reading experience more } \\
\text { interesting }\end{array}$ & $\mathrm{P}$ & 0 & 14.3 & 85.7 & 2.857 & 0.358 & 4 \\
\hline & I can improve my listening & $\mathrm{F}$ & 0 & 5 & 16 & & & \\
\hline 13 & $\begin{array}{l}\text { skill through the audio files } \\
\text { uploaded on Edmodo }\end{array}$ & $\mathrm{P}$ & 0 & 23.8 & 76.2 & 2.761 & 0.436 & 6 \\
\hline
\end{tabular}




\begin{tabular}{|c|c|c|c|c|c|c|c|c|}
\hline \multirow[b]{2}{*}{14} & Edmodo allows me to get & $\mathrm{F}$ & 0 & 2 & 19 & \multirow[b]{2}{*}{2.904} & \multirow[b]{2}{*}{0.300} & \multirow[b]{2}{*}{3} \\
\hline & $\begin{array}{l}\text { immediate feedback from my } \\
\text { teacher. }\end{array}$ & $\mathrm{P}$ & 0 & 9.5 & 90.5 & & & \\
\hline \multirow[b]{2}{*}{15} & Edmodosupports cooperative & $\mathrm{F}$ & 0 & 2 & 19 & \multirow[b]{2}{*}{2.904} & \multirow[b]{2}{*}{0.300} & \multirow[b]{2}{*}{3} \\
\hline & $\begin{array}{l}\text { learning through working in } \\
\text { groups. }\end{array}$ & $\mathrm{P}$ & 0 & 9.5 & 90.5 & & & \\
\hline \multirow[b]{2}{*}{16} & Edmodoallows me to & $\mathrm{F}$ & 0 & 2 & 19 & \multirow[b]{2}{*}{2.904} & \multirow[b]{2}{*}{0.300} & \multirow[b]{2}{*}{3} \\
\hline & $\begin{array}{l}\text { participate in online } \\
\text { discussions. }\end{array}$ & $\mathrm{P}$ & 0 & 9.5 & 90.5 & & & \\
\hline \multirow{2}{*}{17} & Edmododevelops my & $\mathrm{F}$ & 0 & 3 & 18 & \multirow{2}{*}{2.857} & \multirow{2}{*}{0.358} & \multirow{2}{*}{4} \\
\hline & autonomous learning skills. & $\mathrm{P}$ & 0 & 14.3 & 85.7 & & & \\
\hline \multirow[b]{2}{*}{18} & complement & $\mathrm{F}$ & 0 & 0 & 21 & \multirow[b]{2}{*}{3} & \multirow[b]{2}{*}{0} & \multirow[b]{2}{*}{1} \\
\hline & $\begin{array}{l}\text { classroom teaching and } \\
\text { learning. }\end{array}$ & $\mathrm{P}$ & 0 & 0 & 100 & & & \\
\hline \multirow{2}{*}{19} & $\begin{array}{l}\text { Edmodopromotes the } \\
\text { effectiveness of EFL }\end{array}$ & $\mathrm{F}$ & 0 & 0 & 21 & \multirow{2}{*}{3} & \multirow{2}{*}{0} & \multirow{2}{*}{1} \\
\hline & $\begin{array}{l}\text { instruction at secondary } \\
\text { stage. }\end{array}$ & $\mathrm{P}$ & 0 & 0 & 100 & & & \\
\hline
\end{tabular}

Table 7 shows that statements $(5,10,18,19)$ score $100 \%$ of students' agreement. The second rank of the agreement measure is for statement (9) scoring a percentage of $95 \%$. Moreover, $91 \%$ of students agree on four benefits of Edmodo mentioned in statements $(2,14,15,16)$. Five other benefits mentioned in statements $(3,6,11$, $12,17)$ score $85.7 \%$ of students' agreement. Statement (8) has the fifth rank with $81 \%$ of students' agreementwhereas statement (13) has the sixth rank with $76 \%$ of students' agreement. Furthermore, $76 \%$ of students agree on statement (1) whereas $61 \%$ of students agree on statement (4). The least approved benefit of Edmodo is in statement (7) scoring $66 \%$ of students agreement.

\subsection{Testing the Third Question}

A descriptive statistical analysis of Edmodo challenges has also been made.

Table 8. Descriptive statistics of students' challenges when using Edmodo

\begin{tabular}{llllll}
\hline Dimensions & $\mathrm{N}$ & Mean & Std. Deviation & Percent & Rank \\
\hline Technical difficulties & 21 & 10.8571 & 2.24245 & 72.3 & 1 \\
Financial difficulties & 21 & 1.6190 & .80475 & 53.9 & 2 \\
Total & 21 & 12.4760 & 2.63854 & 69.3 & \\
\hline
\end{tabular}

Table 8 shows that technical challenges score $72 \%$ of students' agreement whereas financial ones score $53 \%$.

Table 9. Rank, median and standard deviation values of students' challenges when using Edmodo

\begin{tabular}{|c|c|c|c|c|c|c|c|c|}
\hline \multirow{2}{*}{ No } & \multirow{2}{*}{ Item } & \multirow{2}{*}{$\begin{array}{l}\text { Frequency/ } \\
\text { Percentage }\end{array}$} & \multicolumn{3}{|l|}{ Options } & \multirow{2}{*}{ Median } & \multirow{2}{*}{$\begin{array}{l}\text { Standard } \\
\text { Deviation }\end{array}$} & \multirow{2}{*}{ Rank } \\
\hline & & & Dis-agree & Neutral & Agree & & & \\
\hline \multirow{2}{*}{1} & \multirow{2}{*}{$\begin{array}{l}\text { I lack access to computers or } \\
\text { any mobile devices at home. }\end{array}$} & $\mathrm{F}$ & 12 & 5 & 4 & \multirow{2}{*}{1.61} & \multirow{2}{*}{.804} & \multirow{2}{*}{6} \\
\hline & & $\mathrm{P}$ & 57.1 & 23.8 & 16.7 & & & \\
\hline \multirow{2}{*}{2} & Edmodo requires long time & $\mathrm{F}$ & 5 & 11 & 5 & \multirow{2}{*}{2.00} & \multirow{2}{*}{.707} & \multirow{2}{*}{4} \\
\hline & to master its use. & $\mathrm{P}$ & 23.8 & 52.4 & 23.8 & & & \\
\hline \multirow[b]{2}{*}{3} & I need to learn some & $\mathrm{F}$ & 6 & 8 & 7 & \multirow{2}{*}{ 2. 04} & \multirow{2}{*}{.804} & \multirow[b]{2}{*}{3} \\
\hline & $\begin{array}{l}\text { troubleshooting technology } \\
\text { tasks to help myself when }\end{array}$ & $\mathrm{P}$ & 28.6 & 38.1 & 33.3 & & & \\
\hline
\end{tabular}


using Edmodo.

4

Students may use Edmodo $\mathrm{F}$
as more of a social
networking site than a ${ }^{\text {P }}$ learning tool.

I dislike using Edmodo

Mobile because the $F$

5 small-sized screen causes me difficulty in navigation $\mathrm{P}$ and typing.

I get frustrated by using $\mathrm{F}$

6

Edmodo Mobile, because of

the slow-speed internet on $\mathrm{P}$ my mobile

9

0

0

0

6

28.6
4

19

7

33.3

5

23.8

19

14

10
8

1.95

2.67

.483

1

66.7

2.19

.872

2

Table 9 indicates that the small-sized screen of Edmodo Mobile has $66 \%$ of the agreement measure. The slow-speed internet of Edmodo Mobile has the second rank getting $47 \%$ of students' agreement whereas $33 \%$ of students agree on the challenge regarding the need to learn some troubleshooting technology tasks when using Edmodo. The possibility of using Edmodo as more of a social networking site than a learning tool has scored $19 \%$ whereas the lack of access to computers or any mobile devices has the lowest rank scoring only $16.7 \%$ of students' agreement.

\section{Discussion}

In exploring the effects of using Edmodo on Saudi female students' attitudes towards EFL learning, it appears that, while most students hold positive attitudes towards EFL learning, these positive attitudes become considerably stronger after using Edmodo. A combination of traditional in-class instruction and an online classroom community via Edmodo is significantly verified to be an effective factor in generating more positive attitudes towards learning English. These results coincide with those of Alseweed (2009) who believes that students' attitudes towards EFL learning may change according to many factors like the learning environment and the methods of teaching being used. The use of Edmodo as a new Internet technology, as recommended by Al-Shammari (2007), has introduced an innovative scenario to the traditional Saudi EFL instructionwhich will automatically affect their EFL learning practices. These positive changes build on what has been discovered so far by Majid (2011) and Thongmak (2013) about the usefulness of Edmodo, making these results even more specific. However, it is worth-noticed that the main common value behind these positive attitudes is instrumentally oriented (Al-Zubeiry, 2012; Alfawzan, 2012) which confirm that most of the Saudi students see English as playing a vital role in their academic lives.

More interesting are the results in terms of the students' perceptions towards the use of Edmodo. Findings display obvious conformity of the various benefits which Edmodo can provide to meet students' needs in their learning environment. These findings support the emerging consensus that learners should take the advantages offered by new technologies to improve their learning opportunities (Hanafiah, 2012). As a social interaction means, Edmodo reveals an adequately high level of acceptance (Kongchan, 2012). The chat features of Edmodo allow students to broaden both the type and amount of their communication offeringthem opportunities to increase their confidence and motivation. Edmodo can also help a student overcome isolation providing a shy student with information that facilitates face-to-face encounters with other students or with the teacher. As a Course Management System, Edmodo facilitates uploading, storing and sharing of learning resources in the form of courses, assessments, documents and manuals that complement students' in-class learning. It also serves as a document repository allowing students to gain access to relevant classroom materials 24/7 and making EFL instruction a continuous process that is not limited to the seating capacity of the classroom. Furthermore, Edmodo can facilitate the development of English language skills. It is found to be helpful in acquiring new English vocabulary $(100 \%)$, sharing writing with teacher and peers $(95 \%)$, improving spelling and grammar (85\%), enjoying reading experiences $(85.7 \%)$ and developing listening skills (76 \%). The notion of providing students with an English online communicative environment to practice language skills and to develop their linguistic competences has already been mentioned by Robertson (2008), Al-Jarf (2005) and Tsai and Ernst (2009). Finally, the pedagogical purposes of Edmodo have the highest score of students' agreement. With 
reference to earlier studies, similar findings have been obtained (Majid, 2011; Thongmak, 2013; Kongchan, 2012). A possible interpretation might be the prospect of usingEdmodo as a tool to encourage social and active learning that is learner-centered and informal. A more important interpretation is the potential for using Edmodo to support distance learning and to fulfill physical classroom instruction. Another interpretation might be attributed to the feature of feedbacks. Any content that a student posts instantly starts receiving comments, reviews, opinions, and additional information on that topic either by the teacher or by other students in Edmodo groups. By doing this, more discussions can be formed, and more avenues can be created for fostering independence and self-directed learning. Furthermore, Edmodo offers unique opportunities for collaboration among students in which they can improve their team building and cooperative learning skills.

As forstudents' challenges, the small-sized screen and the slow-speed internet of Edmodo Mobile are found to be poorly suited forstudents' needs. Earlier researchers (Stockwell, 2008; Motiwalla, 2007) already mentioned an evidence of such resistance. The absence of troubleshooting skills is also found to impede the pace of technology-mediated learning in the classroom. This conclusionsupports earlier findings Alebaikan and Troudi (2010) and Almaini (2013) regarding technological immaturity, lack of training and the low computing skill level of students. Such challenges are essentially attributed to the fact that many Saudi secondary school students have never experienced online learning before. However, the fear of using Edmodo as more of a social networking site than a learning toolappears unlikely to happen here due to the secure learning platform of the website in which no personal student pages can be created and to the careful teacher-directed monitoring. As for the financial challenges, only a low share of the earlier assumptions of Stroud (2010) and Almaini (2013) is supported here. This, however, does not negate the fact that financial barriersare still an existing impediment to the integration of Internet technology in education.

\section{Conclusion}

While an EFL classroom may be limited to words spoken and written by instructors, and is trapped in hard copies of the materials distributed for reference, blended learning via Edmodo goes far and beyond. The twin benefits of both traditional and contemporary learning methodologies are pronounced. While the students can benefit from the personal communication brought in by classroom and face-to-face interaction, the collaborative environment provided by Edmodo ensures that knowledge is no longer contained in places defined by geography and can be shared and viewed transparently. It is also vital to recognize that the role of this website should be considered as a facilitating tool for EFL teachers to design a communicative and non-threatening classroom. In this respect, English teachers should be aware of their important roles as classroom instructors and innovators whose tasks are to provide modern tools that complement their teaching and maximize student-student and teacher-student interactions (Barnawi, 2009). Saudi Ministerial support should be also reinforced for promoting the integration of such technologies, to which the younger generation seems to be rather attached, in EFL education. However, even though the great potential for the use of such contemporary learning tools in EFL education is increasingly realized, yet careful thinking is needed to find the best way to leverage these emerging tools in order to improve our EFL teaching and learning practices and to catch up with the pace of global technological developments.

\section{Recommendations}

It is strongly suggested that EFL teachers should do more to utilize useful Web 2.0 tools in order to extend their students' learning outside the classroom. They should also change their teaching habits offering their students innovative opportunities to improve their self confidence, to monitor their own learning and to practice their language skills in and outside the classroom. For trainers, it is highly recommended to establish on-going, well-structured, computer and Internet programs for the professional development of EFL teachers. It is also recommended that teachers go through the experience of being online students themselves (Al-Mahmood and McLoughlin, 2004). This can change their conceptions of teaching and will allow for significant reflection on their teaching practices. For EFL curriculum developers, it is advantageousto evaluate and update EFL curriculum in order to meet the needs of new-generation students, giving particular attention to Web 2.0 technologies. For researchers in EFL instruction, there is a need for future replications of this study. Further analysis of the educational level, gender and age dimensions and their relation to the use of Edmodo in EFL learning is also needed. Possible areas for moreresearch can address students' achievement and motivation, teachers' perceptions and preparedness to utilize this technology and possible ways to make it suit the unique needs and requirements of students.

\section{Acknowledgements}

The author would like to extend her appreciation and gratitude to her supervisor Prof. Dr. Yousif A. 
Alshumaimeri for his insight and expertise that greatly assisted this study. Over all, these different kinds of contributions supported the author very much to complete this study.

\section{References}

Al-Asmari, A. (2005). The Use of the Internet among EFL Teachers at the College of Technology in Saudi Arabia (doctoral dissertation). Ohio State University. OhioLINK. Retrieved August 22, 2013, from https://etd.ohiolink.edu/ap:10:0::NO:10:P10_ACCESSION_NUM:osu111908994

Alebaikan, R., \& Troudi, S. (2010). Blended learning in Saudi universities: Challenges and perspectives. ALT-J, Research in Learning Technology, 18(1), 49-59. http://dx.doi.org/10.1080/09687761003657614

Alfawzan, M. (2012). Saudi Students' Attitudes towards the Utility of English and Their Willingness to Learn It. Open SIUC. Open Access Theses. Retrieved September 5, 2013, from http://opensiuc.lib.siu.edu/theses/782/

Aljabre, A. (2012). An Exploration of Distance Learning in Saudi Arabian Universities: Current Practices and Future Possibilities. International Journal of Instructional Technology and Distance Learning, 9(2), 21-28. Retrieved October 1, 2013, from http://www.itdl.org/Journal/Feb_12/Feb_12.pdf\#page=25

Al-Jarf, R. (2005). Using Three Online Course Management Systems in EFL Instruction. Paper presented at The $4^{\text {th }}$ Asia CALL Conference. Sorabol College, Geongju, South Korea. Retrieved September 15, 2013, from http://files.eric.ed.gov/ fulltext/ ED497937.pdf

Alkaff, A. (2013). Students' Attitudes and Perceptions towards Learning English. AWEJ, 4(2), 106-121. Retrieved September 7, 2013, from http://www.awej.org/images/AllIssues/Volume4/Volume4Number2June 2013/8.pdf

Al-Mahmood, R., \& McLoughlin, C. (2004). Re-learning through e-learning: Changing conceptions of teaching through online experience. In R. Atkinson, C. McBeath, D. Jonas-Dwyer, \& R. Phillips (Eds.), Beyond the comfort zone: Proceedings of The $21^{\text {st }}$ ASCILITE Conference (pp. 37-47). Perth, 5-8 December. Retrieved September 27, 2013, from http://www.ascilite.org.au/conferences/perth04/procs/al-mahmood.html

Almaini, Y. (2013). Issues in integrating information technology in learning and teaching EFL: The Saudi Experience. Merit Search Journal of Education and Review, 1(5), 107-111. Retrieved October 16, 2013, from http://meritresearchjournals.org/er/content/2013/June/Al-Maini.pdf

Al-Seghayer, K. (2012). Status and functions of English in Saudi Arabia. Saudi Gazette. Retrieved September 21, 2013, from http://www.saudigazette.com.sa/

Alseweed, M. (2009). Attitudes of Saudi Secondary School Level Students TowardsLearning of English as a Foreign Language. Journal of Arabic and Human Sciences, Qassim University, 2(1), 9-22. Retrieved September 19, 2013, from http://publications.qu.edu.sa/ojs/index.php/arab/article/view/85/83

Alshahrani, K. (2012). Conceptions and responses to e-learning: The case of EFL teachers and students in a Saudi Arabian university. Monash University LinguisticsPapers, 8(1), 21-31. Retrieved September 19, 2013, from http://www .academia.edu/1823367/

Al Shammari, M. (2007). Saudi English as a Foreign Language Learners'Attitudes toward Computer-Assisted Language Learning (Doctoral Dissertation). West VirginiaUniversity, USA. Retrieved August 28, 2013, from http://wvuscholar.wvu.edu:8881/

Al-Shehri, S. (2011). Context in our pockets: Mobile phones and social networking astools of contextualizing language learning. 10th World Conference on Mobile and Contextual Learning, Beijing, China, 18-21 October. Retrieved September 2, 2013, from http://mlearn.bnu.edu.cn/source/ten_outstanding_papers/

Al-Zubeiry, H. (2012). The Socio-psychological orientations of Saudi learners of Englishas a foreign Language. Umm Al Qura University Journal of Languages and Literature (Vol. 8). Retrieved October 12, 2013, from http://uqu.edu.sa/files2/tiny_mce/plugins/filemanager/files/4280212/AR-8--5.pdf

Arroyo, G. (2011). On-Line Social Networks: Innovative Ways towards the Boost of Collaborative Language Learning. ICT for Language Learning (4th ed.). Retrieved Oct 7, 2013, from http://conference.pixelonline.net/

Attewell, J., Savill-Smith, C., \& Douch, R. (2009). The impact of mobile learning: Examining what it means for teaching and learning. Retrieved October 26, 2013, from http://www.caryloliver.com/

Barnawi, O. (2009). The Internet and EFL College Instruction: A Small-Scale Study of EFL College Teachers' Reactions. International Journal of Instructional Technology and Distance Learning, 6(6), 47-64. Retrieved 
September 20, 2013, from http://www.itdl.org/Journal/Jun_09/article04.htm

Chen, B., \& Bryer, T. (2012). Investigating Instructional Strategies for Using Social Mediain Formal and Informal Learning. The International Review of Research in Open and Distance Learning (IRRODL), 13(1). Retrieved September 17, 2013, from http://www.irrodl.org/index.php/irrodl/article/view/1027/2073

Coffey, N. (2012). The Advantages and Disadvantages of Mobile Apps for Language Learning. EZINE Articles. Retrieved October 11, 2013, from http://EzineArticles.com/

Cohen, L., Manion, L., \& Morrison, K. (2007). Research methods in education (6th ed.). USA, New York, Routledge.

Course Management System (CMS). (n.d.). In Techopedia. Retrieved October 14, 2013, from http://www.techopedia.com/definition/6651/course-management-system-cms

Downes, S. (2007). An introduction to connective knowledge. Presented at the International Conference on Media, Knowledge \& Education-Exploring New Spaces, Relations and Dynamics in Digital Media Ecologies. Retrieved October 8, 2013, from http://www.downes.ca/post/33034

Fujimoto, C. (2012). Perceptions of mobile language learning in Australia: How ready are learners to study on the move? Thejalt call Journal, 8(3), 165-195. Retrieved September 25, 2013, from http://journal.jaltcall.org/articles/8_3_Fujimoto.pdf

Gagne, R. (1984). Learning Outcomes and Their Effects: Useful Categories of HumanPerformance. American Psychologist, 39(4), 377-385. Retrieved September 3, 2013, from http://www.davidlewisphd.com/courses/ 8001/EDD8001/SUM12/ 1984-Gagne.pdf

Grosseck, G. (2009). To use or not to use web 2.0 in higher education? World Conference on Educational Sciences. Procedia Social and Behavioral Sciences, 1, 478-482. Retrieved October 6, 2013, from http://webpages.csus.edu/ sac43949/ pdfs/to\%20use\%20or\%20not\%20to\%20use.pdf

Hanafiah, M. (2012). Fostering mobile learning apps in English language learning. Retrieved October 28, 2013, from http://www.academia.edu/

Haygood, E., Garner, R., \& Johnson, S. (2012). Blended Learning: Using Web 2.0S to Enhance Classroom Instruction. Interlink Alliance. Retrieved October 10, 2013, from http://www.cehs.ohio.edu/

Kongchan, C. (2012). How a Non-Digital-Native Teacher Makes Use of Edmodo. ICT for Language Learning (5th ed.). Retrieved August 24, 2013, from http://conference.pixel-online.net/

Majid, N. (2011). The Use of Information Technology in Teaching English: An Attemptto Develop Student-Centered Learning at Telkom Polytechnic. Prosidingkonferensi Nasional ICT-M Politeknit Telkom (KNIP). Retrieved August 13, 2013, from http://openjurnal.politekniktelkom.ac.id/

Meerts, J. (2003). Course Management Systems. EDUCAUSE Evolving Technologies Committee. Retrieved September 10, 2013, from http://net.educause.edu/ir/library/pdf/dec0302.pdf

Motiwalla, L. F. (2007). Mobile learning: A framework and evaluation. Computers \& Education, 49(3), 581-596. Retrieved September 29, 2013, from http://www.qou.edu/arabic/researchProgram/distanceLearning/mobile Learning.pdf

Robertson, C. (2008). Integration of Moodle Course Management System (CMS) into an EFL Writing Class. The JALT CALL Journal, 4(1), 53-59. Retrieved October 7, 2013, from http://journal.jaltcall.org/articles/4_1_ Robertson.pdf

Siemens, G. (2004). Connectivism: A learning theory for the digital age. E-learn space. Retrieved September 6, 2013, from http://www.elearnspace.org/Articles/connectivism.htm

Stockwell, G. (2008). Investigating learner preparedness for and usage patterns of mobilelearning. ReCALL, 20(3), 253-270. http://dx.doi.org/10.1017/S0958344008000232

Stroud, C. (2010). Edmodo: A White Paper. Connecting Technology \& Curriculum. Winthrop University. Retrieved August 17, 2013, from http://coe.winthrop.edu/

Thongmak, M. (2013). Social Network System in Classroom: Antecedents of Edmodo (C) Adoption. Journal of e-Learning and Higher Education, 2013. http://dx.doi.org/10.5171/2013.657749

Tsai, Y., \& Ernst, C. (2009). The Model and Implementation of a Course-Management-System (CMS)-assisted EFL Reading Strategy Instruction. International Journal on Digital Learning Technology, 1(3), 203-223. Retrieved September 12, 2013, from http://www.ijdlt.org/download.php?dir=papers\&filename=00052016- 
03-ijdlt3-4.pdf

Turkmen, G. (2012). Using Social Networking in EFL Classroom in Higher Education. Conference proceedings of "eLearning and Software for Education" (eLSE), 1, 350-354. Retrieved August 26, 2013, from http://www.ceeol.com

Witherspoon, A. (2011). Edmodo: A Learning Management System. Retrieved August, 12, 2013, from http://www.poweredwithtechnology.com/

Wolf, A., \& College, E. (2007). Students' attitudes towards social networks and modalities. Retrieved September 3, 2013, from http://alisonwolfe.com/wordpress/

Wu, W., \& Hua, C. (2008). The application of Moodle on an EFL collegiate writing environment. Journal of Education \& Foreign Languages and Literature, 7, 45-56. Retrieved September 28, 2013, from http://web.chu.edu.tw/ wswu/publications/papers/ journals/06.pdf

Zaidieh, A. (2012). The Use of Social Networking in Education: Challenges and Opportunities. World of Computer Science and Information Technology Journal (WCSIT), 2(1), 18-21. Retrieved September 11, 2013, from http://wcsit.org/pub/2012/vol.2.no.1/The\%20Use\%20of\%20Social\%20Networking\%20in\%20 Education\%20Challenges\%20and\%20Opportunities.pdf

\section{Appendix A}

Kingdom of Saudi Arabia

Ministry of Higher Education

King Saud University

Department of Curriculum and Instruction

\section{MA TESOL}

Dear student,

Thank you for taking the time to complete this questionnaire. Your feedback is important to me in identifying the usefulness and the challenges of integrating Edmodo in secondary school EFL classrooms and measuring its effect on students' attitude towards EFL learning.

Your responses will be anonymous, confidential and for scientific use only.

If you have any questions, please contact the researcher at fatimakathiri@gmail.com

Thank You for your cooperation.

A. Secondary school students' attitudes towards EFL learning

\begin{tabular}{|c|c|c|c|c|}
\hline No & Items & Agree & Neutral & Disagree \\
\hline 1 & I really want to learn English. & & & \\
\hline 2 & I recommend more English classes for secondary schools. & & & \\
\hline 3 & I like using English when chatting with my friends. & & & \\
\hline 4 & I like learning English through technology. & & & \\
\hline 5 & It is easy for me to learn English. & & & \\
\hline 6 & I always need someone to help me in my English assignments. & & & \\
\hline 7 & English is hard for me to learn. & & & \\
\hline 8 & I believe I can improve my English. & & & \\
\hline 9 & English language helps me to communicate with the world around me. & & & \\
\hline 10 & I think learning English increases my self-confidence. & & & \\
\hline 11 & I just want to learn English to pass exams. & & & \\
\hline 12 & I need English when I search the internet. & & & \\
\hline 13 & Learning English is important for my future studies. & & & \\
\hline
\end{tabular}


B. Secondary school students' perceptions towards using Edmodo in EFL learning

\begin{tabular}{|c|c|c|c|c|}
\hline No & Items & Agree & Neutral & Disagree \\
\hline 1 & Edmodo meets my needs such as mobility and social communication. & & & \\
\hline 2 & $\begin{array}{l}\text { Edmodo offers me more opportunities to interact with my teacher and } \\
\text { peers outside classroom. }\end{array}$ & & & \\
\hline 3 & $\begin{array}{l}\text { Students who are shy to participate in class, usually feel more } \\
\text { comfortable communicating online via Edmodo. }\end{array}$ & & & \\
\hline 4 & $\begin{array}{l}\text { Edmodo saves effort and time by doing and submitting assignments } \\
\text { electronically. }\end{array}$ & & & \\
\hline 5 & $\begin{array}{l}\text { Edmodoservices like (SMS messages, alerts, notes) give me a running } \\
\text { record of when assignments are due and a description of what is } \\
\text { expected. }\end{array}$ & & & \\
\hline 6 & $\begin{array}{l}\text { When absent, I can easily access class materials and assignments } \\
\text { through Edmodo. }\end{array}$ & & & \\
\hline 7 & Edmodoreduceslearning cost (e.g. photocopying, designing posters). & & & \\
\hline 8 & Edmodo helps me practicing my language skills through conversations. & & & \\
\hline 9 & $\begin{array}{l}\text { Edmodogives me a chance to share my writing with my teacher and } \\
\text { peers. }\end{array}$ & & & \\
\hline 10 & Edmodo helps me acquiring new English vocabulary. & & & \\
\hline 11 & $\begin{array}{l}\text { Edmodohelps me to improve my spelling and grammar when posting in } \\
\text { complete words and sentences (e.g. "you" not "u", "I" not "i"). }\end{array}$ & & & \\
\hline 12 & Edmodohelps to make my reading experience more interesting. & & & \\
\hline 13 & $\begin{array}{l}\text { I can improve my listening skill through the audio files uploaded on } \\
\text { Edmodo. }\end{array}$ & & & \\
\hline 14 & Edmodo allows me to get immediate feedback from my teacher. & & & \\
\hline 15 & Edmodosupports cooperative learning through working in groups. & & & \\
\hline 16 & Edmodoallows me to participate in online discussions. & & & \\
\hline 17 & Edmododevelops my autonomous learning skills. & & & \\
\hline 18 & Edmodocan complement classroom teaching and learning. & & & \\
\hline 19 & $\begin{array}{l}\text { Edmodopromotes the effectiveness of EFL instruction at secondary } \\
\text { stage. }\end{array}$ & & & \\
\hline
\end{tabular}

C. Challenges of using Edmodo in secondary school EFL learning

\begin{tabular}{|c|c|c|c|c|}
\hline No & Items & Agree & Neutral & Disagree \\
\hline 1 & I lack access to computers or any mobile devices at home. & & & \\
\hline 2 & Edmodo requires long time to master its use. & & & \\
\hline 3 & $\begin{array}{l}\text { I need to learn some troubleshooting technology tasks to help myself } \\
\text { when using Edmodo. }\end{array}$ & & & \\
\hline 4 & $\begin{array}{l}\text { Students may use Edmodo as more of a social networking site than a } \\
\text { learning tool. }\end{array}$ & & & \\
\hline 5 & $\begin{array}{l}\text { I dislike using Edmodo Mobile because the small-sized screen causes me } \\
\text { difficulty in navigation and typing. }\end{array}$ & & & \\
\hline 6 & $\begin{array}{l}\text { I get frustrated when using Edmodo Mobile because of the slow-speed } \\
\text { internet on my mobile. }\end{array}$ & & & \\
\hline
\end{tabular}


Would you like to add further challenges, comments, suggestions?

Thank You for your cooperation

\section{Copyrights}

Copyright for this article is retained by the author(s), with first publication rights granted to the journal.

This is an open-access article distributed under the terms and conditions of the Creative Commons Attribution license (http://creativecommons.org/licenses/by/3.0/). 